\title{
ASSESSMENT OF SUITABLE LANDFILL SITE USING GEOSPATIAL TECHNIQUES: A CASE STUDY OF RAIPUR URBAN REGION, CHHATTISGARH, INDIA
}

\author{
Amit P Multaniya ${ }^{*}{ }^{\circledR}$ (iD), Sanju Verma ${ }^{2}$, M. K Beg ${ }^{1}$ \\ ${ }^{1}$ Chhattisgarh Council of Science \& Technology, Raipur, CG, India \\ ${ }^{2}$ National Informatics Centre, Raipur, CG, India
}

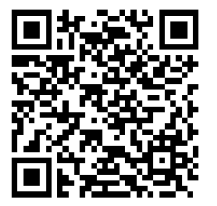

DOI: https://doi.org/10.29121/granthaalayah.v9.i3.2021.3778

Article Type: Research Article

Article Citation: Amit P Multaniya, Sanju Verma, and M. K Beg. (2021). ASSESSMENT OF SUITABLE LANDFILL SITE USING GEOSPATIAL TECHNIQUES: A CASE STUDY OF RAIPUR URBAN REGION, CHHATTISGARH, INDIA. International Journal of Research GRANTHAALAYAH, 9(3), 132-148. https://doi.org/10.29121/granthaa layah.v9.i3.2021.3778

Received Date: 01 March 2021

Accepted Date: 27 March 2021

\section{Keywords:}

Geospatial Technique

Landfill Site Selection

Weighted Linear Combination

(WLC)

Multi-Criteria Decision Analysis (MCDA) and Raipur

\section{ABSTRACT}

Currently, the solid waste management work of Raipur is being done in a completely traditional way, which is very expensive and time consuming. The site selection method using Geospatial techniques can function as a decision support tool for enhanced efficient and effective management of municipal solid waste. This Study's aim was to develop landfill siting by crossing major barriers such as political, economic and environmental pressures for the execution of a suitable site criteria by employing combination of geospatial technique and Weighted Linear Combination (WLC) of Multi-Criteria Decision Analysis (MCDA) in Raipur urban area. The preliminary step of the methodology was geospatial operation and Study that disqualified all areas unsuitable for landfill siting. The insularity of suitable criteria for landfill site was generated based on published information on solid waste management, existing laws and regulatory necessities, as well as the existing local conditions. The different suitability criteria considered are soil, land use land cover, digital elevation model (DEM), surface waters, transport network, lithology and geological structures. Criteria were mapped using the geospatial technique; each criterion was identified and weighted by score for overlay to create suitability maps using GIS. The final results showed that there are more locations for landfills for Raipur urban area. In the present Study there are sporadic areas identified as suitable sites for landfill location. In the site suitability analysis $74.79 \%$ area found not suitable for landfill siting, $20.93 \%$ least suitable and $3.25 \%$ moderate suitable. Out of the remaining area, $1.03 \%$ area is found most suitable.

\section{INTRODUCTION}

A huge amount of solid waste from the urban area being generated conjoined with effective solid waste management is a major challenge facing most of the growing cities due to population growth and economic development have a lack of planning, inadequate technology, and good governance. Solid waste disposal through open waste dumping is very common in unplanned cities of developing countries due to poor solid waste management. (Adewumi J. R. Ajibade F. O., 2017; Akinbile et al., 2016; Ali et al., 2014; Ferronato et al., 2017; Fides K. Kirimi, 2014; J. R. Adewumi and Fidelis O. Ajibade, 2015; Rahmat et al., 2017). The challenge is more serious in growing cities where population growth and economic activities have led to an increase in solid waste. (Fides K.

(C) 2021 The Author(s). This is an open access article distributed under the terms of the Creative Commons Attribution License, which permits unrestricted use, distribution, and reproduction in any medium, provided the original author and source are credited. 
Kirimi, 2014) However, considering the adverse impacts of wastes on the environment and public health (Akinbile et al., 2016; Yukalang et al., 2017) different techniques have been utilized for reducing and recycling solid waste, waste disposal via landfill is an essential part of all waste management schemes.

Locating proper sites for dumping solid waste from natural resources, settlement, water bodies, transport network, and geological structure is necessary for the management of solid waste in an appropriate method, as solid wastes in urban areas mostly consists of plastics, glass, chemical products, and kitchen wastes that have complex formation and late decomposition characteristics (Mussa and Suryabhagavan, 2019).

The suitability site selection for the disposal of solid needs analytical assessment of several factors (environmental, financial, social, and technical factors) (Nas et al., 2010) because inappropriate landfill sites have critical environmental issues on the constituents of the environment (Al-Anbari et al., 2018). Environmental factors are extremely crucial since landfills may influence the bio-physicochemical characteristics of the environment and the ecology of the landfill site area (Al-Anbari et al., 2018; Kontos et al., 2005).

The process of solid waste management consists of the collection, transportation, and disposal. Disposal of solid waste is to place it in properly designed, constructed, and managed landfills, where it is safely contained (Fides K. Kirimi, 2014). Yet, the selection of an appropriate site for solid waste dumping is a daunting assignment, complex spatial difficulty, involving multiple criteria that involve the use of spatial analysis (Chang et al., 2008).

In recent years, Geospatial techniques have been playing a major role in the process of decision-making. Considering all the factors in the selection of siting a landfill, the Geographical Information Systems (GIS) and multicriteria decision analysis (MCDA) is an effective tool to resolve the landfill site selection problem (Şener et al., 2011). The benefit of this technique to site selection is to save time and cost. It also offers digital data inventory for long-term monitoring of the site.

For landfill sites selection, researchers have used various techniques which include the use of a weighted linear combination (WLC) method and spatial cluster analysis (SCA) (Al-Hanbali et al., 2011; Moeinaddini et al., 2010; Saeed et al., 2003; Salmon Mahini and Gholamalifard, 2006), merging fuzzy procedure and GIS (Akbari et al., 2008; Ali et al., 2014; Kharat et al., 2016; Khorram et al., 2015) a combined use of MCDA and GIS (Abdulhasan et al., 2019; Ajibade et al., 2019; Alanbari et al., 2014; Alkaradaghi et al., 2019; Chabuk et al., 2019; Demesouka et al., 2014; Fides K. Kirimi, 2014; Gautam et al., 2020; Ibrahim Mohammed et al., 2018; Özkan et al., 2019; Randazzo et al., 2018; Uday Kiran Buddi, 2017) and GIS digital map overlay techniques (Balaguru, 2015; Mussa and Suryabhagavan, 2019; Nallusamy et al., 2017; Nishant.T, Prakash M.N, 2010).

Multiple criteria decision analysis is premised on making actual decisions from several options by appraising them based on a set of measurable criteria. Landfill site selection is a multi-criterion decision-making process in which both multi-criteria and GIS methodology are used. This technique helps the decision-maker to set priorities to make the best decision by reducing the complex method. When combined with GIS, Remote sensing, and MCDA it offers a powerful tool in the selection of a suitable site (Fides K. Kirimi, 2014; Randazzo et al., 2018).

Solid waste management is one of the primary position environmental challenges in India and major issues to the rapidly growing city of Raipur which is capital of Chhattisgarh India where the practice of solid waste management is mainly open dump system with only a few designated site without provision of daily/frequent covering of disposing of wastes (Jharia, 2014; RMC, 2018). The dumpsite exposes the public, especially those at proximity to undesirable levels of noxious waste which have bad effects on human health. The problem is intensified by the fact that the siting for the dump was not selected by any scientific Study that took into consideration the underlying soil structure, topography, water, geological structures, transport network proximity from protected areas, and settlement.

There is, need to carry out effective and efficient solid waste disposal for the unplanned city of Raipur Chhattisgarh India. Main objective of the Study is to incorporate MCDA approach with GIS to identify suitable landfill site which will not be hazardous to the environment and shall ensure sustainable landfill site management system in Raipur Chhattisgarh. Before this Study, no such Study has been done in this area. For the first time in an unplanned area, an attempt has been made by taking basic parameters like Drainage Network, Transport Network, Lithology, Geological Structures, Soil, Land Use Land Cover, and Slope with aid of the weighted linear combination (WLC) model is one the most widely used GIS-based decision rules to demarcate sustainable landfill site. 


\section{MATERIALS AND METHODS}

\subsection{STUDY AREA}

Raipur Urban Region including New (Nava) Raipur area lies approximately $21^{\circ} 02^{\prime} 50^{\prime \prime}$ to $21^{\circ} 19^{\prime} 50^{\prime \prime}$ north latitude and 81 $32^{\prime} 00^{\prime \prime}$ to $81^{\circ} 53^{\prime} 50^{\prime \prime}$ east longitude, location map is shown in Figure 1. Raipur Urban Region including New Raipur area is at an altitude of 298.15 m meters above sea level and covers an area of approximately 636.665 km2 with total Population (Census 2011) -1,123,558 inhabitants and Density - 6463/km2. The urban area is bounded by geographical features; the Mahanadi river in the east, the Kharun in the west, Mahanadi Canal in the north, and Khilora Nala in the south of the urban boundary.

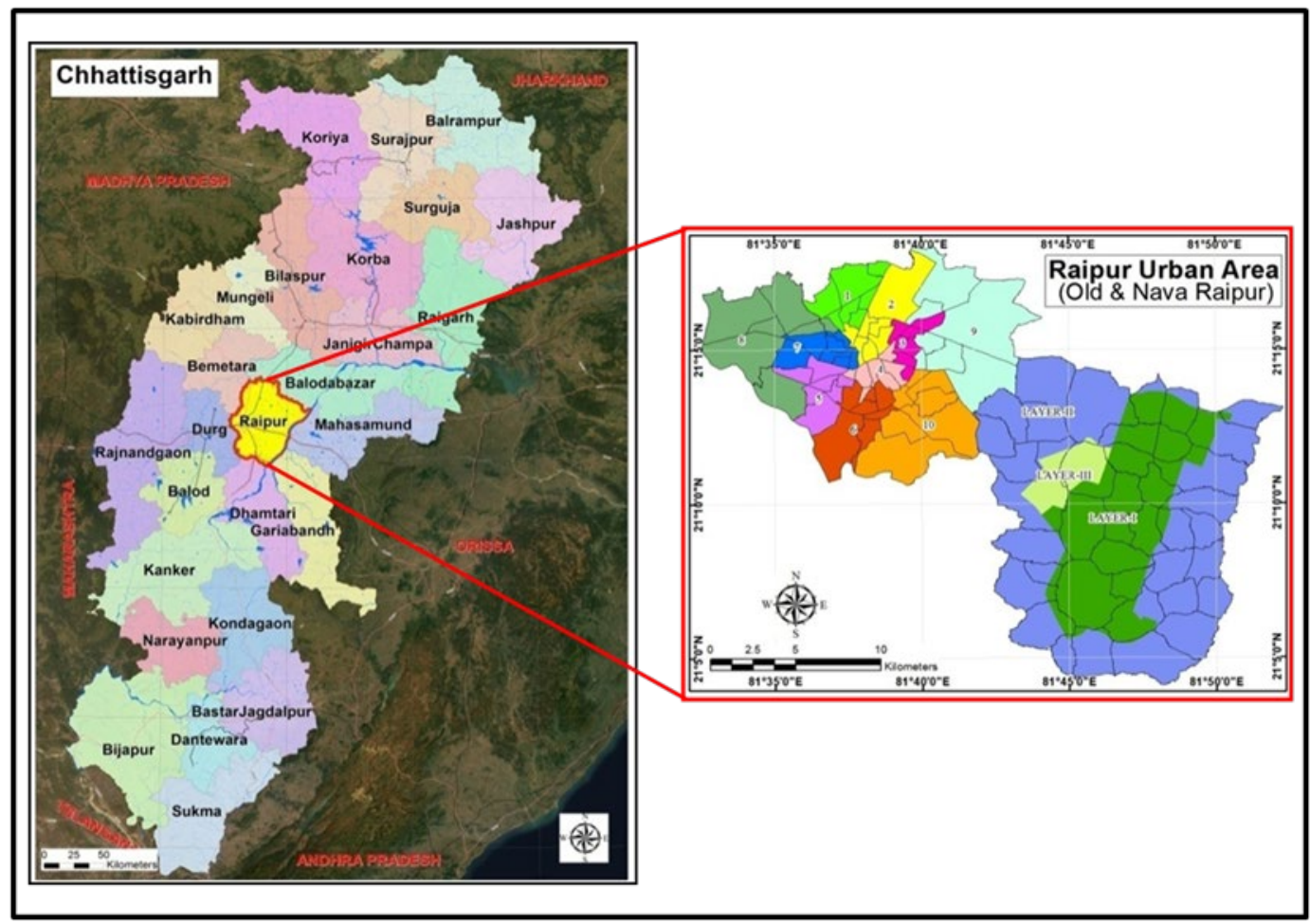

Figure 1: Location Map of the Study Area.

\subsection{METHODOLOGY}

As mentioned earlier, there are no specific criteria for selecting solid waste disposal sites in Raipur urban area. The criteria used in this study were based on criteria derived from literature review with adjustments to local desired priorities and requirements. Six suitability criteria: distance from transport networks, distance from Drainage network and water body, distance from faults and lithological conditions, soil characteristic, landuse landcover condition and slope, were used in this study. Transport network, Drainage and surface water bodies, geological structure and LULC data were delineated and updated from Cartosat 1 the year of 2018 having $2.5 \mathrm{~m}$ resolution of the Study area. The weighted linear combination (WLC) technique is a decision rule for deriving composite maps using GIS. The methodology adopted for the Study is divided into two subgroups: i) site selection criteria using Weighted Linear Combination (WLC) and ii) GIS overlay analysis(Al-Hanbali et al., 2011; Moeinaddini et al., 2010; Saeed et al., 2003; Salmon Mahini and Gholamalifard, 2006). Ancillary data were collected, maneuvered, analyzed, and overlay in the GIS environment to determine the suitable landfill sites. The methodology adopted for the present Study is shown in the flowchart (Figure 3).

Digital Elevation Model (CartoDEM 30*30 m resolution, (Source: https://bhuvanapp3.nrsc. gov.in) was used to derive slope. These criteria were divided into constraint and factor criteria where the former represents unacceptable areas, latter represented the acceptable areas for landfill siting. GIS buffering was used to screen out 
unsuitable areas based on the defined criteria. All the constraint criterion maps were overlaid to produce the final factor map. Seven important assessment criteria were identified i.e. soil texture, land use land cover, slope, surface waters, transport network, lithology, and geological structures in the Study area.

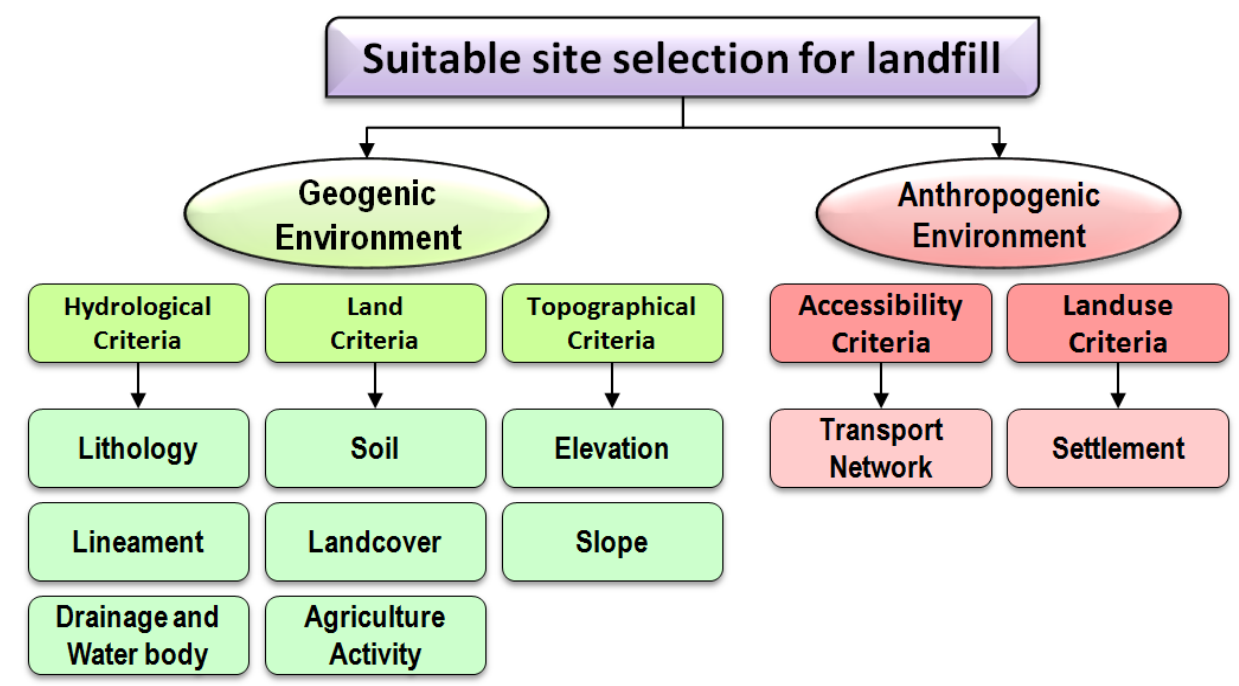

Figure 2: Tree diagram of the decision process developed for selection of suitable landfill sites

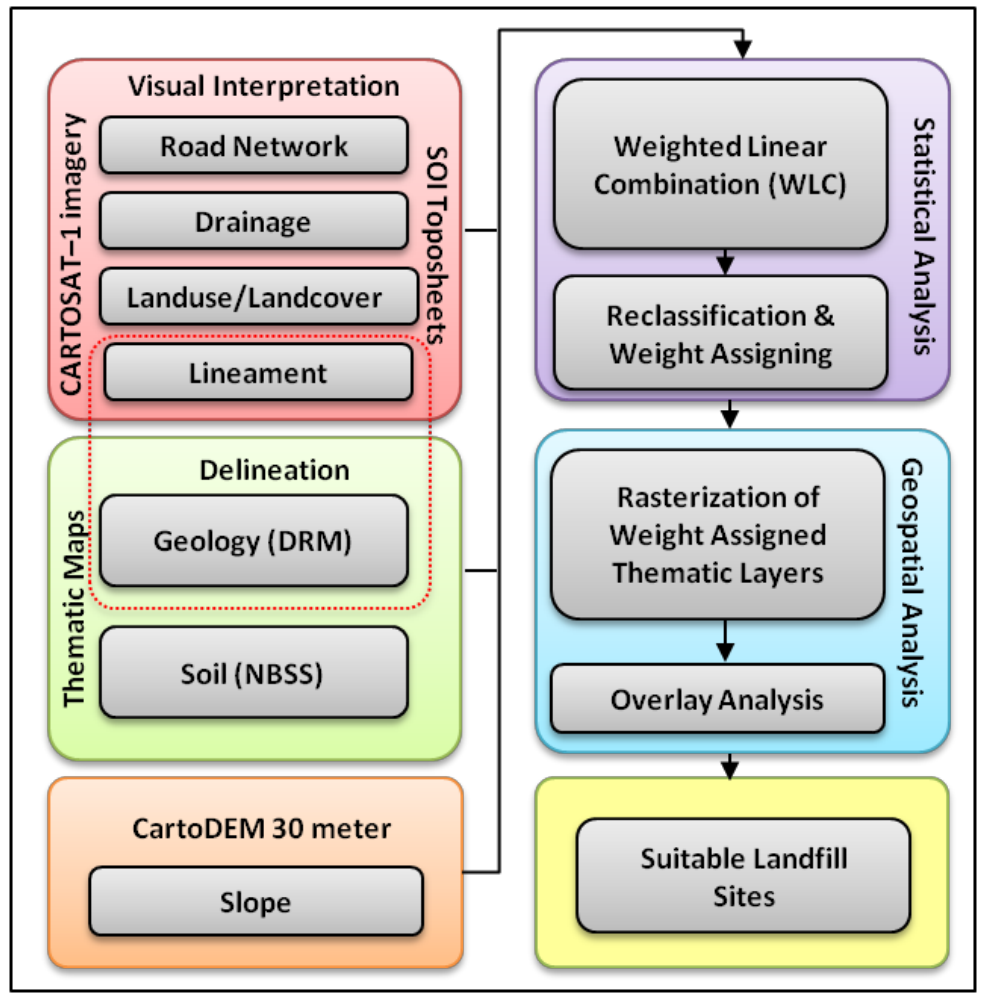

Figure 3: Flow chart illustrating technical process incorporated in this Study

Suitable criteria for landfill site selection in Raipur region, Chhattisgarh, India were generated based information published on landfill criteria as well as the prevailing local conditions (Central Public Health \& Environmental Engineering Organization-CPHEEO Manual). Suitable areas were identified from Suitable Site maps and classified of highly suitable, moderately suitable, least suitable and not suitable and for being used as site locations. This was done by weighting processes where each map layer was both internally weighted based on the minimum and maximum distance to features (environmental judgment) and externally weighted using Multi- 
Assessment of Suitable Landfill Site Using Geospatial Techniques: A Case Study of Raipur Urban Region, Chhattisgarh, India

Criteria Decision Analysis (MCDA) based on its relative importance to the waste disposal problem (Fides K. Kirimi, 2014).

\subsection{CRITERIA USED IN THE WLC AND GIS ANALYSIS}

Table 1: Geospatial data used in this Study

\begin{tabular}{|c|c|c|c|}
\hline Factor & Description & Format & Source \\
\hline Drainage network & Refers to the drainage system & Vector, & (CCoST) Interpretation of CartoSAT -1 \\
\hline $\begin{array}{c}\text { Transport } \\
\text { Network }\end{array}$ & $\begin{array}{c}\text { Any Transport network e.g. } \\
\text { Highway and any local } \\
\text { connectivity }\end{array}$ & $\begin{array}{c}\text { Vector, } \\
\text { Shapefile }\end{array}$ & $\begin{array}{c}\text { (CCoST) Interpretation of CartoSAT -1 } \\
\text { Satellite Data and delineation from Survey } \\
\text { of India Toposheet }\end{array}$ \\
\hline $\begin{array}{c}\text { Lithology and } \\
\text { Geological } \\
\text { Structures }\end{array}$ & $\begin{array}{c}\text { Any planner fracture, } \\
\text { discontinuity and type of } \\
\text { aquifers }\end{array}$ & $\begin{array}{c}\text { Vector, } \\
\text { Shapefile }\end{array}$ & $\begin{array}{c}\text { (CCoST \& DGM) Interpretation of CartoSAT - } \\
\text { 1 Satellite Data and delineation from District } \\
\text { resource map }\end{array}$ \\
\hline Soil & $\begin{array}{c}\text { Soil depth and textures } \\
\text { Vector, } \\
\text { Shapefile }\end{array}$ & $\begin{array}{c}\text { (NBSS\&LUP) National Bureau of Soil Survey } \\
\text { and Land Use planning }\end{array}$ \\
\hline LULC & $\begin{array}{c}\text { Lector, } \\
\text { Shapefile }\end{array}$ & $\begin{array}{c}\text { (CCoST) Interpretation of CartoSAT -1 } \\
\text { Satellite Data }\end{array}$ \\
\hline Slope & Stability of Land surface & Raster & (CCoST) CartoDEM \\
\hline
\end{tabular}

\subsection{DRAINAGE AND SURFACE WATER SOURCE}

Drainage delineated from Survey of India toposheets 64G11 \& 64G12 and updated from Cartosta-1 imagery and created various buffer zones for assigning the influence weight in GIS environment. Drainage network map of the Study area is shown in Figure 4.

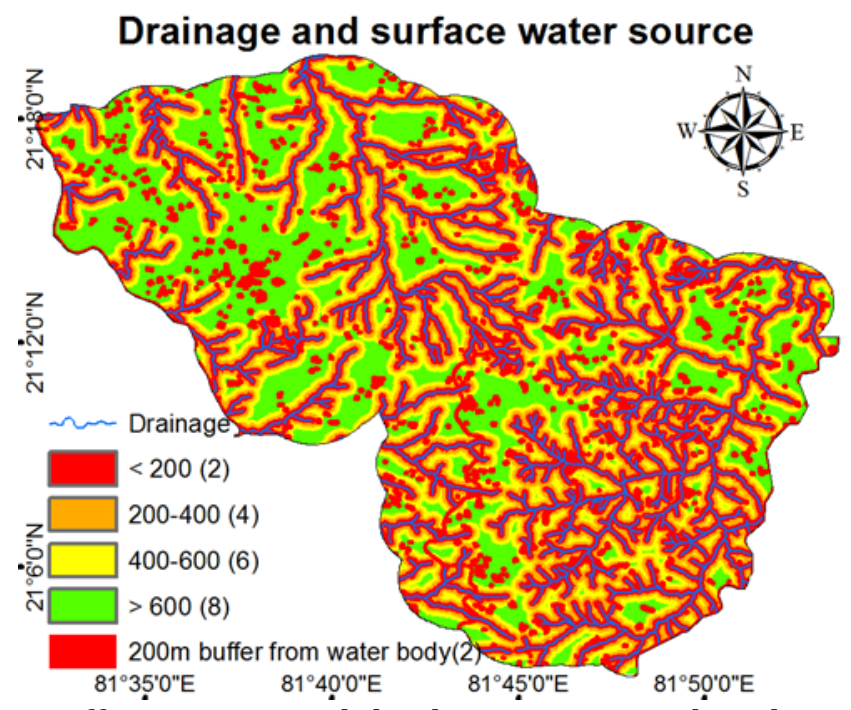

Figure 4: Buffer zone around the drainage network and water bodies

\subsection{TRANSPORT NETWORK}

Accessibility to landfill location must be close to road network for effortless movement and reducing comparative costs of waste material. Road and Rail network delineated from Cartosat-1 imagery and Survey of India toposheets no 64G11 \& 64G12 and created various buffer zones. Transport network map of the Study area is shown in Figure 5. 


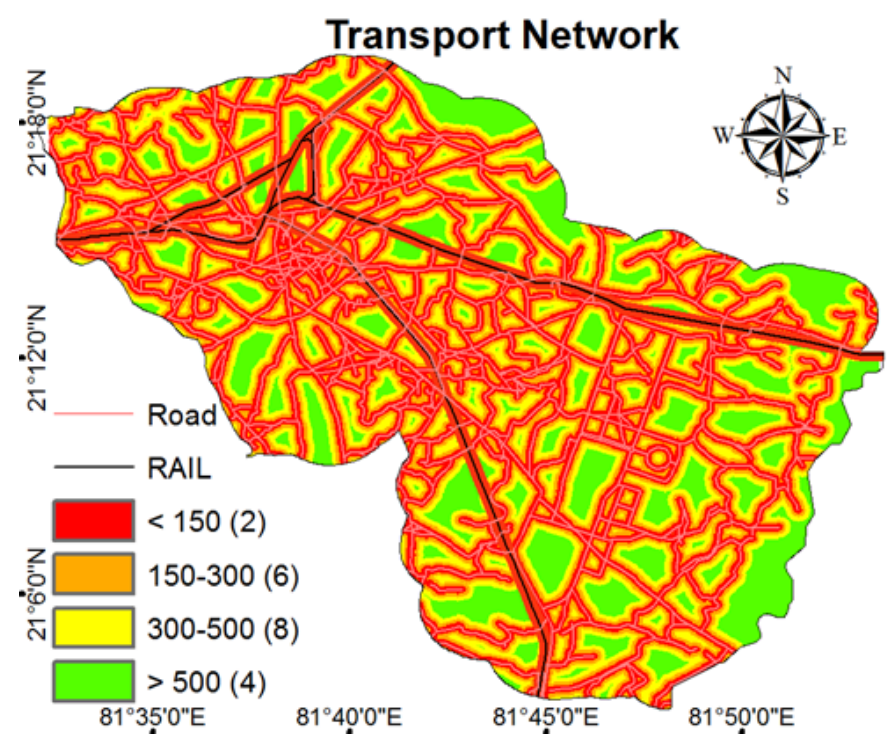

Figure 5: Buffer zone around the transport network

\subsection{LITHOLOGY AND STRUCTURE}

The lithology of the Study area constitutes Arenite and Shale having low permeability due to low degree of weathering and fracture that's covers the major portion of the Study area. Other major rock type observed was Alluvium and Laterite (District Resource Map, Raipur). It is also characterized by the occurrence of geological structures within the different rock type of Study area and its great importance in landfill site investigation. Geology map of the Study area is shown in Figure 6.

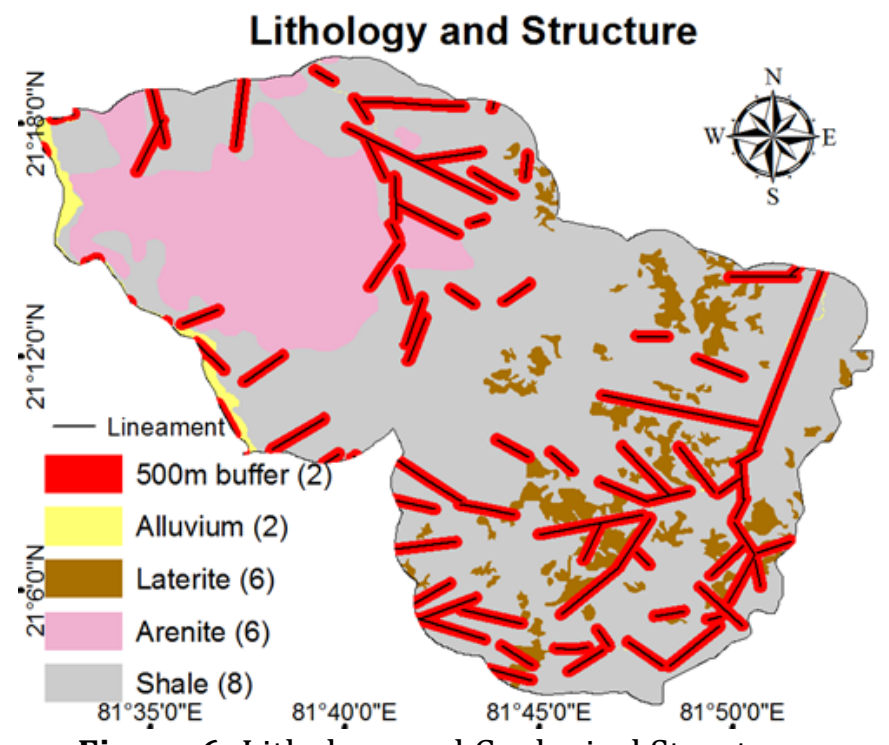

Figure 6: Lithology and Geological Structures

\subsection{SOIL}

Soil map of the Study area was collected from the National Bureau of Soil Survey and Land Use planning (NBSS\&LUP), Nagpur, Government of India. Different class of soil delineated and categorized from geo referenced Soil map. The soil map indicates the four soil texture i.e. clay, clay loam, sandy clay loam and gravelly sandy clay loam. Soil map of the Study area is shown in Figure 7. 


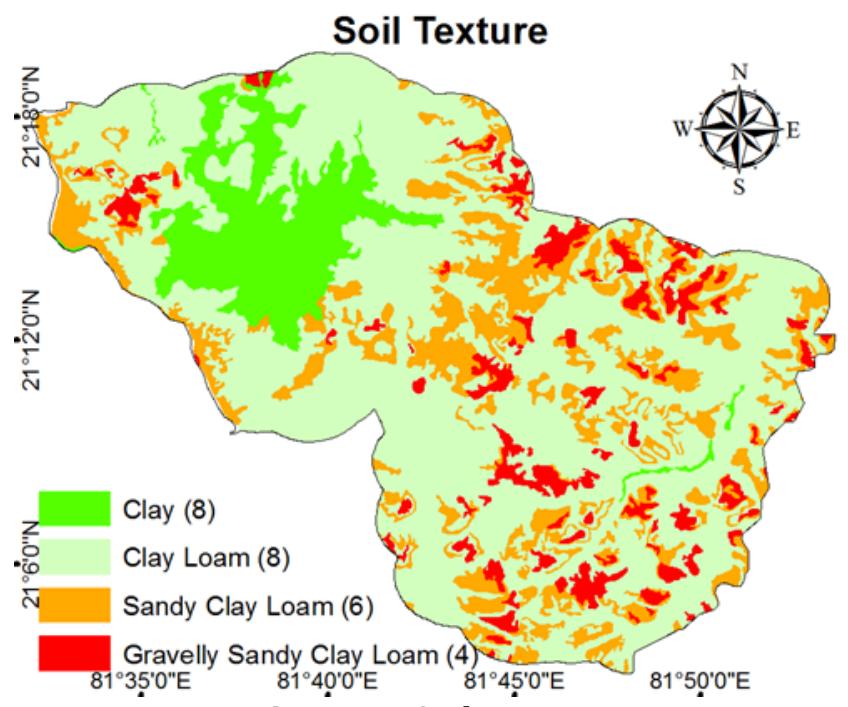

Figure 7: Soil Texture

\subsection{LAND USE LAND COVER}

Cartosat 1 year of 2018 and LISS IV year of 2018 merged data having the resolution $2.5 \mathrm{~m}$ with ground truthing from different class of Land use / Land cover (LULC) were used to prepare map. The LULC map specifies the areas of agriculture activity, Forest plantation, waste land, Built up and water bodies. LULC map of the Study area is shown in Figure 8.

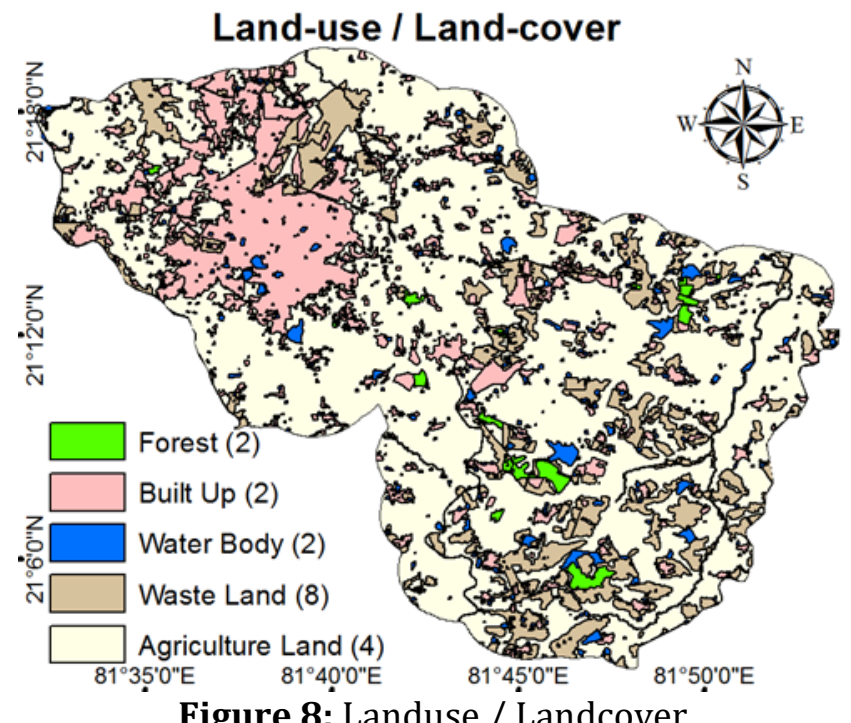

Figure 8: Landuse / Landcover

\subsection{SLOPE}

Digital Elevation Model (DEM) layer is captured from CartoDEM of $30 \mathrm{~m}$ resolution was used in the present Study. The slope layer is created from DEM in GIS environment. The Study area has plain topography and the contour distance is far from each other. The Slope layer is categorized into 4 classes i.e. $<2,2-4,4-10$ and $>10$. Slope map of the Study area is shown in Figure 9. 


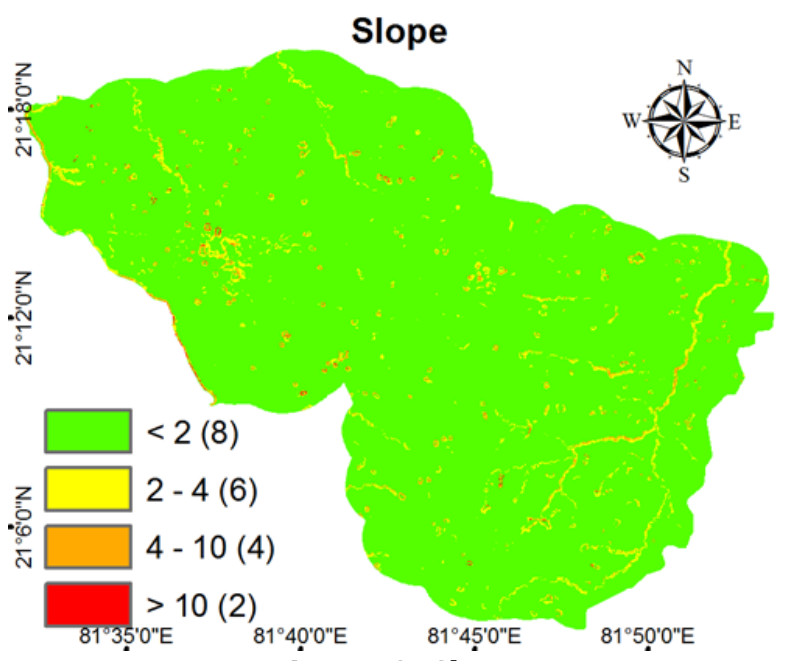

Figure 9: Slope

\subsection{THE WLC AND GIS PROCEDURE}

All GIS software systems provide the basic tools for evaluating MCDA model. The primary issues, however, relate to the standardization of criteria scores and the development of the weights. The weighted linear combination (WLC) model is one the most widely used GIS-based decision rules(Al-Hanbali et al., 2011; Eastman et al., 1995; Malczewski, $2006,2000)$. It is one of the most often used decision models in GIS. The method is often applied in land use/suitability analysis, site selection, and resource evaluation problems. The primary reason for its popularity is that the method is very easy to implement within the GIS environment using map algebra operations and cartographic modeling. The method is also easy-to-understand and intuitively appealing to decision makers. WLC can be operationalized using any GIS system having overlay capabilities. The overlay techniques allow the attribute map layers (input maps) to be aggregated in order to determine the composite map layer (output map). Six suitability criteria: distance from transport networks, distance from Drainage network and water body, distance from faults and lithological conditions, soil characteristic, landuse landcover condition and slope, has been taken for Landfill suitability Study. There were many steps that were performed in GIS in order to get the final required criterion in this study (e.g., Buffer, Clip, Extract, Overlay, Proximity, Convert, Reclassify and Map Algebra, etc.). Each criterion was reclassified, and then given ranking, to comply with a specific scheme. Then, a final composite map was produced using WLC (Al-Hanbali et al., 2011; Eastman et al., 1995; Hopkins, 1977; Malczewski, 2006). The weights and scores were assigned after several discussions with the local experts, and decision makers, in addition to the previous knowledge of the study area. As a general rule, it was decided to give higher weightings to factors that affect directly on the community such as distance from urban areas, distance from agricultural lands, and distance from the faults, whereas the other factors, which have lower effects on the community or can be adjusted by engineering processes, were assigned lower weightings(Al-Hanbali et al., 2011; Moeinaddini et al., 2010; Saeed et al., 2003; Salmon Mahini and Gholamalifard, 2006). The Layers, the criteria used, their scores, and their weights are summarized in Table 2.

\subsection{ESTABLISHING THE THEME WEIGHTS AND CRITERIA SCORE}

As indicated above, the most prevalent procedure for multi criteria evaluation is the weighted linear combination. The literature review was used to identify inconsistencies and to develop the best fit weights, the Weight linear combination comparison analysis was established by equation (1) with a weighted linear combination, factors are combined by applying a weight to each followed by a summation of the results to yield a suitability map: i.e.

$\mathrm{S}=\sum$ wixi

Where $S$ is the suitability, wi is a weighting of factor $i$, and $x i$ is the criterion score of factor $i$. 
Once the value was established, the module Multi-Criteria Decision Analysis (MCDA) was used to combine the factors and constraints in the form of a weighted linear combination. Score assigned for each objective are geographically coherent and meaningful in terms of the criteria specified. The procedure is optimized for speed and has the effect of multiplying each criterion by its weight, adding the results, and then successfully multiplying the result by each of the constraints.

Table 2: Score, Weight and map rating of each of criteria used for land fill site suitability:

\begin{tabular}{|c|c|c|c|c|c|}
\hline Theme & Criteria & Suitability & Score & Weight & $\begin{array}{l}\text { Map rating of } \\
\text { each criteria }\end{array}$ \\
\hline \multirow[t]{5}{*}{ Drainage and water source } & $<200 \mathrm{~m}$ & Not Suitable & 2 & \multirow[t]{5}{*}{0.2} & 0.4 \\
\hline & $200-400 \mathrm{~m}$ & Least Suitable & 4 & & 0.8 \\
\hline & $400-600 \mathrm{~m}$ & Moderate Suitable & 6 & & 1.2 \\
\hline & $>600 \mathrm{~m}$ & Highly Suitable & 8 & & 1.6 \\
\hline & Water Body & Not Suitable & 2 & & 0.4 \\
\hline \multirow[t]{4}{*}{ Transport Network } & $<150 \mathrm{~m}$ & Not Suitable & 2 & \multirow[t]{4}{*}{0.2} & 0.4 \\
\hline & $150-350 \mathrm{~m}$ & Moderate Suitable & 6 & & 1.2 \\
\hline & $350-500 \mathrm{~m}$ & Highly Suitable & 8 & & 1.6 \\
\hline & $>500 \mathrm{~m}$ & Least Suitable & 4 & & 0.8 \\
\hline \multirow[t]{5}{*}{ Lithology \& Structure } & Alluvium & Not Suitable & 2 & \multirow[t]{5}{*}{0.15} & 0.3 \\
\hline & Arenite & Moderate Suitable & 6 & & 0.9 \\
\hline & Laterite & Moderate Suitable & 6 & & 0.9 \\
\hline & Shale & Highly Suitable & 8 & & 1.2 \\
\hline & Lineament $<500 \mathrm{~m}$ & Not Suitable & 2 & & 0.3 \\
\hline \multirow[t]{4}{*}{ Soil } & Clay & Highly Suitable & 8 & \multirow[t]{4}{*}{0.15} & 1.2 \\
\hline & Clay loam & Highly Suitable & 8 & & 1.2 \\
\hline & Gravelly sandy clay loam & Least Suitable & 4 & & 0.6 \\
\hline & Sandy clay loam & Moderate Suitable & 6 & & 0.9 \\
\hline \multirow[t]{5}{*}{ LULC } & Agriculture & Least Suitable & 4 & \multirow[t]{5}{*}{0.2} & 0.8 \\
\hline & Built Up & Not Suitable & 2 & & 0.4 \\
\hline & Forest Plantation & Not Suitable & 2 & & 0.4 \\
\hline & Waste Land & Highly Suitable & 8 & & 1.6 \\
\hline & Water Body & Not Suitable & 2 & & 0.4 \\
\hline \multirow[t]{4}{*}{ Slope } & $0-2^{\circ}$ & Highly Suitable & 8 & \multirow[t]{4}{*}{0.1} & 0.8 \\
\hline & $2-4^{\circ}$ & Moderate Suitable & 6 & & 0.6 \\
\hline & $4-10^{\circ}$ & Least Suitable & 4 & & 0.4 \\
\hline & $>10^{\circ}$ & Not Suitable & 2 & & 0.2 \\
\hline
\end{tabular}

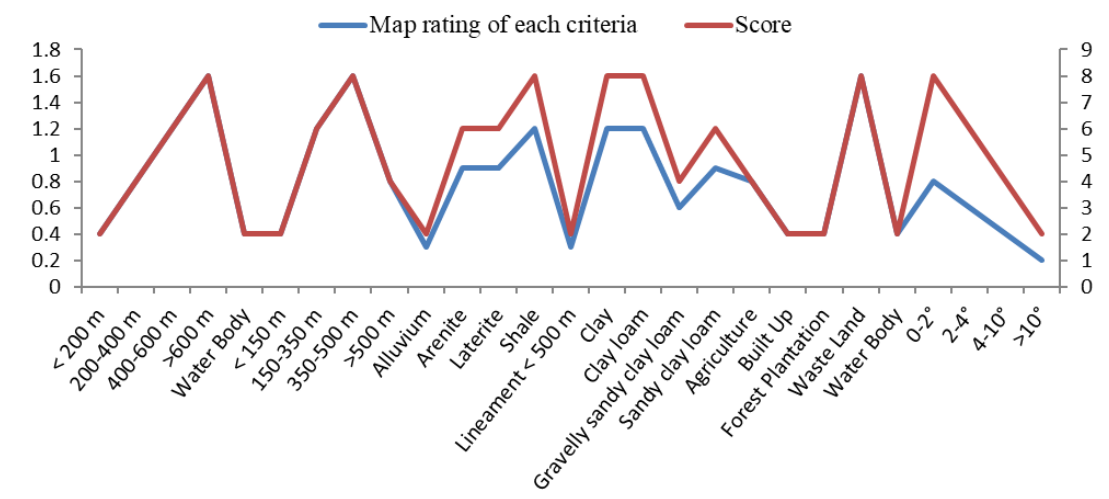

Figure 10: Single-Criteria overlay suitability trend graph for land suitability. 


\section{RESULTS AND DISCUSSIONS}

The Study area is the capital region and one of the fast-developing townships in India. Raipur has witnessed a high growth rate in population, along with the rapid increase in infrastructure and residential colonies. At present the urban solid waste is being discarded at a site in a village called Sarona near to Kharun river which is a fifteenyear-old dump yard. The site is almost filled with solid waste and it may not be able to accommodate any further. Similarly, due to increase population, urbanization, and industrialization the quantum of Municipal Solid Waste generated increased many folds and unmanaged municipal solid waste disposal particularly has lead to serious socio-environmental problems. This Study signifies an important step in addressing a critical gap in the detection of landfill sites and to augment cost-effectiveness and efficiency of waste management efforts. Due to their ability to deal with large volumes of spatial information from various resources geospatial technology is ideal for site selection studies (Alkaradaghi et al., 2019; Malczewski, 2006; Mussa and Suryabhagavan, 2019). All the reviewed papers considered a landfill site selection/evaluation problem as a case Study, the majority of the MCDA and GIS overlay articles belong to the deterministic category (Al-Hanbali et al., 2011; Moeinaddini et al., 2010; Saeed et al., 2003; Salmon Mahini and Gholamalifard, 2006). The use of landfill site assessment models produced relatively good outcome in present Study (Poorna and G, 2016). In this Study, ancillary data from various parameters were obtained and after a descriptive analysis, surveyed studies are categorized based on the six criteria in a GIS environment. Then, we used MCDA to determine the relative importance of criteria to each other and WLC method to evaluate the land suitability. All digital maps of the Study area including topographical maps were registered to UTM coordinate system, zone 44N, WGS84 datum. GIS environment is able to perform suitability analysis using Multi-Criteria Decision Analysis (MCDA) and computed six (6) positive landfill site windows for overlay analysis (Karthiheyan and Yeshodha, 2016).

\subsection{DRAINAGE AND SURFACE WATER SOURCE}

The distance from surface water source and drainage is important criteria for selecting a suitable landfill site, because drainage has infiltration capacity. During the monsoon time water drip over drainage and contaminate the potable source of water. Solid waste disposal sites must not be located near to surface water (streams, rivers, lakes, and pond). The NGT directives stated that a $100 \mathrm{~m}$ buffer zone should be maintained around significant water bodies. Most of the surface water in the study area is in the form of streams and tank that occurred during heavy rains in monsoon season. Thus, a score value of 2 was given to a distance of $\leq 200 \mathrm{~m}$, while a score value of 8 was given to distances of $>600 \mathrm{~m}$. A weighting value of 0.2 was given to this factor, because of its influence on the environment. Estimation of drainage distance from the stream is illustrated in Table 2 where 4 classes have been classified on the basis of relative distance from the surface water source (Poorna and G, 2016), 21.48\% and 16.37\% part of the Study area is highly suitable and moderately suitable respectively, whereas, $26.28 \%$ and $35.87 \%$ of the area are least suitable and not suitable respectively for landfill site.

\subsection{TRANSPORT NETWORK}

There is no specific rule of what should be the best distance to place the landfill site. Most studies suggested that the landfill site should be located within a $1 \mathrm{~km}$ buffer from the roads (Al-Hanbali et al., 2011; Chang et al., 2008; Delgado et al., 2008). The landfill sites should not be placed too far from the roads to decrease the cost of transportations. The road network in the study area was delineated from CartoSAT - 1 Satellite Data and Survey of India Toposheet in GIS vector format. Using GIS spatial analysis, a buffer was created around road network at distances mentioned in Table 2. Considering the huge cost of transportation, it was decided to give a score of 4 to the a distance ranges from $>500 \mathrm{~m}$, while distances of less than $500 \mathrm{~m}$ and more than $350 \mathrm{~m}$ were given a score of 8 , as shown in Table 2. A weighting value of 0.2 was assigned to this factor, since this factor can be adjusted by planners and engineers based on the project conditions. According to the transportation network map for landfill sites shows in Figure 5, maximum area (45.41\%) of the Study is not suitable and $27.2 \%$ of the Study area is least suitable, whereas, $18.91 \%$ and $8.48 \%$ of the area are moderately suitable and highly suitable, respectively for landfill site. 
Assessment of Suitable Landfill Site Using Geospatial Techniques: A Case Study of Raipur Urban Region, Chhattisgarh, India

\subsection{LITHOLOGY AND STRUCTURE}

Lithology and structure of potential site turns out to be exceptionally remarkable part in decrease of the spread of contaminants (Şener et al., 2011) Lithology and structure shows that out of total Study area $72.92 \%$ is highly suitable and $18.43 \%$ is moderately suitable for landfill site, whereas, $7.13 \%$ and $1.52 \%$ of the Study area are least suitable and not suitable respectively and shown in Figure 6.

\subsection{SOIL}

Soil should be of sufficiently low permeability to significantly slow the passage of leached from the site (Fides K. Kirimi, 2014). Soil characteristics such as texture and depth shows that out of total Study area, $63.18 \%$ is highly suitable and $18.63 \%$ is moderately suitable for landfill sites, whereas, $7.17 \%$ and $11.02 \%$ of the area are and not suitable respectively and shown in Figure 7.

\subsection{LAND-USE / LAND-COVER}

The land-use / land-cover (LULC) map displays the land utilized by human and natural cover in the Raipur Urban Region including New Raipur area. The majority of the Study area is occupied by agriculture activity. Based on LULC suitability, out of total Study area $14.26 \%$ is highly suitable and $64.07 \%$ moderately suitable for landfill sites, whereas, $0.88 \%$ of the area is least suitable. The remaining $20.80 \%$ of the Study area are not suitable for landfill sites and illustrate in Figure 8.

\subsection{SLOPE}

As per the new rules, construction of landfills on hills shall be avoided. However, transfer stations and processing facilities shall be operational in the hilly areas (Ministry of Environment and Forests Notification New Delhi, the 25th September, 2000). Slope map shows Study area dominated by slope of (0-2 degree) which is highly suitable region, subsequently, moderate sloping area (2-4 degree), least suitable area ( 4-10 degree), not suitable areas ( $>10$ degree) and shown in Figure 9.

\subsection{SUITABILITY ASSESSMENT}

In this study, an arid area (Raipur Urban area as a case study) was selected. Presently, the landfills do not satisfy the required environmental criteria. Various criteria used in landfill site suitability analysis partially evolved and the relative importance of each parameter were determined. It is observed that the parameter used in landfill site selection have a different degree of influence. Seven of the most significant criteria were selected for this purpose. For suitable weight for each criterion, the multi-criteria decision-analysis (MCDA) methods were applied in the GIS environment. GIS-based study of spatial data has been a new specialized process, competent of analyzing complex problem of evaluating different geospatial features for targeting potential areas for siting landfills. Geospatial technique offers unique capacities for automating geospatial analysis for screening all possible sites. The suitable sites selection can be narrowed down using a prescribed MCDA process. This procedure will allow the planners and decision-makers to apply it in other areas in Chhattisgarh that have similar conditions when selecting a new landfill site. 


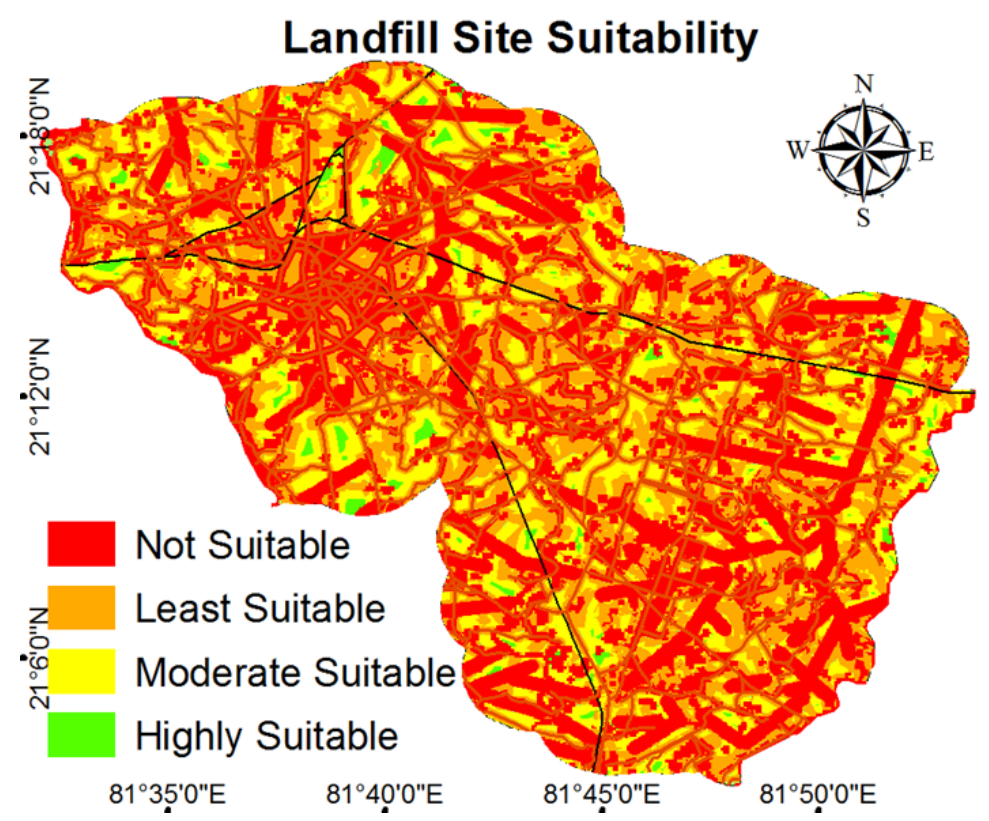

Figure 12: Landfill Site Suitability Map of Raipur Urban Region including New Raipur area

Table 3: Statistical analysis for the Landfill site suitability map

\begin{tabular}{|c|c|c|}
\hline Class & Area (ha) & Area (\%) \\
\hline Not Suitable & 16092.10 & 25 \\
\hline Least Suitable & 31962.52 & 51 \\
\hline Moderate Suitable & 14103.09 & 22 \\
\hline Highly Suitable & 1114.94 & 2 \\
\hline Total & 16092.10 & 100 \\
\hline
\end{tabular}

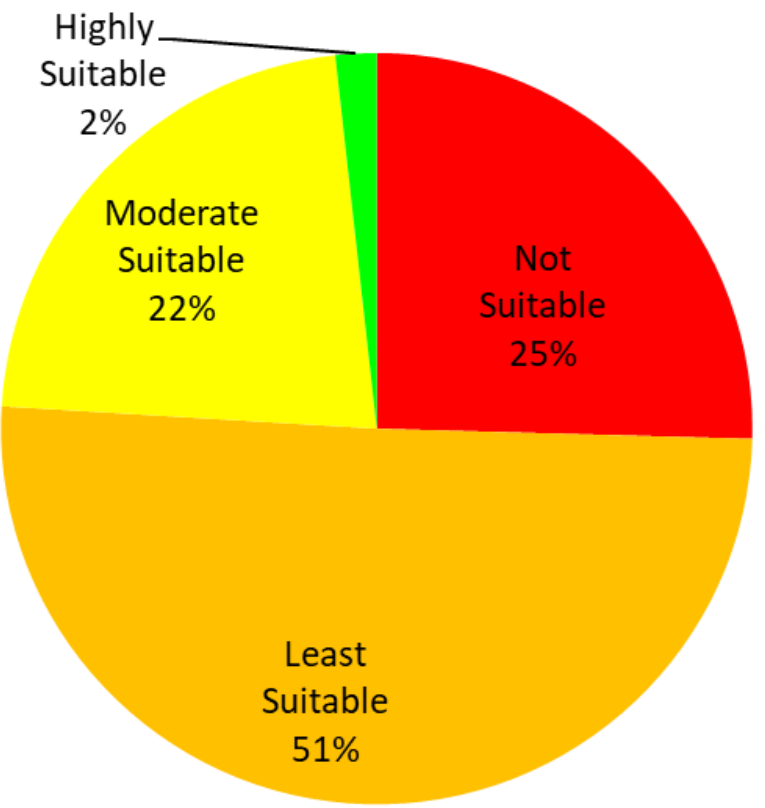

Figure 11: Graphical analysis for the Landfill site suitability map of Raipur Urban Area

To define the rank projection and topology creation of drainage, transport network, lithology, structure, soil, LULC, and slope were converted to separate raster files using weightage and score. For the site suitability analysis, all the raster datasets of each layer having different scores were overlaid and the scores of the individual layer were 
added using the raster calculator tool in GIS. The final scores were reclassified in four classes to generate a suitable map for landfill site which is illustrated in Figure 12. Finally, landfill sites were obtained for landfill in Raipur Urban Region including New Raipur area; the most potential sites are shown in Figure 13. The final results showed that there are more locations for landfills for old and new Raipur urban area. In the present Study there are sporadic areas identified as suitable sites for landfill location. In the site suitability analysis $25 \%$ area found not suitable for landfill siting, $51 \%$ least suitable and $22 \%$ moderate suitable. Out of the remaining area, $2 \%$ area is found most suitable (Table 3).

Based on the land suitability map, the existing solid waste disposal site, as illustrated in Figure 13, is located within "Least suitable" class. This gives an indication that the location of the existing disposal site is in critical situation. The presence of the existing disposal site very close to the river is not recommended, since it can increase contamination in the river water, there is the chances of the health risks to the people who are living near to the river.

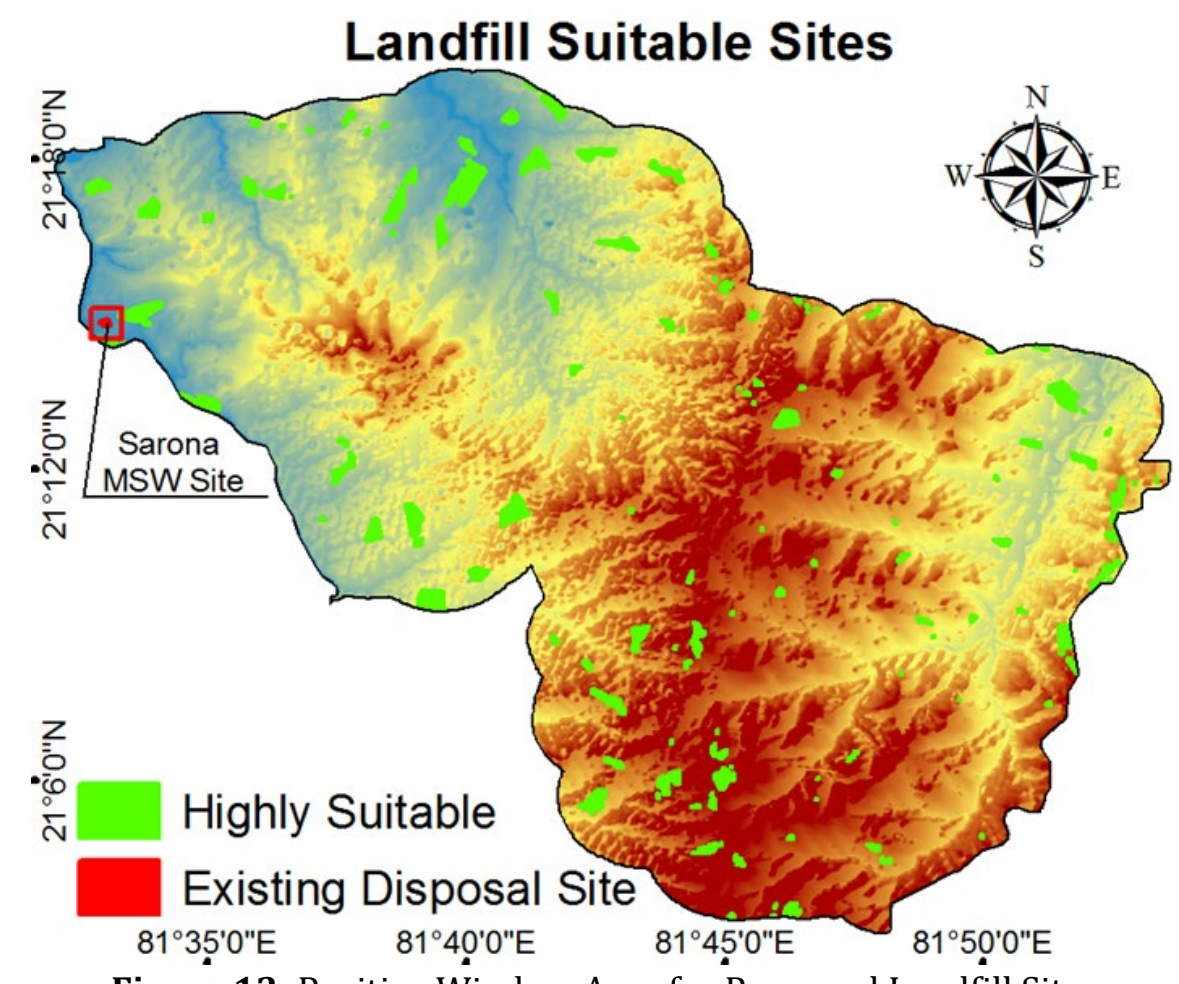

Figure 13: Positive Window Area for Proposed Landfill Sites

The areas of the selected sites were adequate to unload the cumulative quantity of solid waste for future solid waste dumping. The present waste disposal sites in Raipur Urban Region including New Raipur area do not conform to the environmental and scientific criteria, and it influences human health. In a landfill selection procedure, it becomes essential to review the reliability of the method involved in identification of the best candidate site. The study methodology was based on the experts opinion and previous studies in this field by giving proportion values for each assessment criteria according to its importance among other criteria Site selection for landfill corresponds to a complex process due to the implementation of different environmental criteria. Geospatial techniques provides statistical presumption facility in spatial environment which minimize the chances of error in work execution and corroborate that the geospatial techniques are preferable for landfill site selection which enables the identification of areas suitable to host a MSW because of their minimal effect on the environment, protect the human health and, on the other hand, respect the constraints and restrictions imposed by environmental law for landfill siting in scientific manner.

A field survey was conducted to check the conditions of the suggested alternative sites. It was found that most of the suggested sites, from environmental point of view, can be suitable for a new landfill site. But, in terms of 
planning and public opinion there might have different views, which might need further investigations, taking into consideration more detailed engineering, geotechnical, and hydrogeological studies.

\section{CONCLUSIONS AND RECOMMENDATIONS}

Raipur Urban Region including New Raipur area is unplanned and the city has a population density of about 6463/ km2 and generates about 600 tons of waste per day. Solid waste management and disposal in Municipal Corporation at its present status does not fulfill the required conditions (Jharia, 2014). The increasing generation of MSW in the urban area is one of the greatest challenges faced by governmental authorities. In order to mitigate the impacts on the environment and public health, a claim, which necessitates a fast decision making process for final disposal of the MSW, motivates this study. The present Study addresses landfill site management and disposal of Raipur Municipal Corporation to enhance the efficacy of landfill site management efforts. Urban wastes of the Study area consist of a highly assorted mass of pollutant from residential, commercial, and industrial activities to create an environmental problem. An assortment of disposal sites for solid wastes generated in the urban area has always been a challenging task and site selection is the complex process that should have a minimum environmental impact. Research findings show that a combination of MCDA with geospatial technique, featuring a well-structured architecture and the computational power, improves the application potential in urban and regional planning, and gives necessary support to the decision-maker in the appraisal of the waste management difficulty so that a higher level of understanding can be reached in regard to environmental decisions. It has been established beyond every reasonable doubt that geospatial technology is a very important tool for determining the most appropriate locations for setting disposal and it also helps to decide travel routes for waste transportation and disposal.

This present Study acquired data from various sources and integrated into a GIS environment to categorize suitable land for a proper selection process and suggest suitable landfill sites. The integration of GIS and multicriteria decision-making technique establish an environment for transportation and corroborating geospatial data for concern stakeholders. The Study suggests that many areas located in Raipur Urban Region including New Raipur area Urban Region can be alternate to present landfill sites might be suitable from the environment and economic point of view and it minimizes the environmental risk and human health. The present Study is useful for planner and researcher to serve as a guide for further planning, management and development of smart city waste disposals.

\section{SOURCES OF FUNDING}

This research received no specific grant from any funding agency in the public, commercial, or not-for-profit sectors.

\section{CONFLICT OF INTEREST}

The author have declared that no competing interests exist.

\section{ACKNOWLEDGMENT}

The Study is a part of experience in various project work carried out by the first author (Amit Prakash Multaniya) at Chhattisgarh Space Application Centre, CG Council of Science and Technology (CCoST), Govt. of Chhattisgarh. The authors are thankful to Mr. Mudit Kumar Singh, Director General, CCoST for encouraging and providing support to carry out this Study. Authors would also like to thank the staff of CGSAC group who was involved in this Study for their time and guidance.

\section{REFERENCES}

[1] Abdulhasan, M. J., M. M. Hanafiah, M. S. Satchet, H. S. Abdulaali, M. E. Toriman, and A. A. Al-Raad. 2019. "Combining Gis, Fuzzy Logic, and Ahp Models for Solid Waste Disposal Site Selection in Nasiriyah, Iraq." Applied Ecology and Environmental Research 17 (3): 6701-6722. doi:10.15666/aeer/1703_67016722. 
Assessment of Suitable Landfill Site Using Geospatial Techniques: A Case Study of Raipur Urban Region, Chhattisgarh, India

[2] Adewumi J. R. Ajibade F. O., Lasisi K.H. and A. M. Oguntuase. 2017. "Characterization of Municipal Solid Waste Generated in Akure Metropolis," no. August: 11-13.

[3] Ajibade, Fidelis O., Olabanji O. Olajire, Temitope F. Ajibade, Nathaniel A. Nwogwu, Kayode H. Lasisi, Ayopo B. Alo, Titilayo A. Owolabi, and James R. Adewumi. 2019. "Combining Multicriteria Decision Analysis with GIS for Suitably Siting Landfills in a Nigerian State.” Environmental and Sustainability Indicators 3-4 (October). Elsevier Ltd: 100010. doi:10.1016/j.indic.2019.100010.

[4] Akbari, V, M A Rajabi, S H Chavoshi, and R Shams. 2008. "Landfill Site Selection by Combining GIS and Fuzzy Multi Criteria Decision Analysis, Case Study: Bandar Abbas, Iran.” World Applied Sciences Journal 3 (1): 3947.

[5] Akinbile, C. O., F. O. Ajibade, and O. Ofuafo. 2016. "Soil Quality Analysis for Dumpsite Environment in a University Community in Nigeria." Journal of Engineering and Engineering Technology 10 (2): 68-73.

[6] Al-Anbari, Mohammad A., Mohanad Y. Thameer, and Nadhir Al-Ansari. 2018. "Landfill Site Selection by Weighted Overlay Technique: Case Study of Al-Kufa, Iraq." Sustainability (Switzerland) 10 (4): 1-11. doi:10.3390/su10040999.

[7] Al-Hanbali, Ahmad, Bayan Alsaaideh, and Akihiko Kondoh. 2011. "Using GIS-Based Weighted Linear Combination Analysis and Remote Sensing Techniques to Select Optimum Solid Waste Disposal Sites within Mafraq City, Jordan." Journal of Geographic Information System 03 (04): 267-278. doi:10.4236/jgis.2011.34023.

[8] Alanbari, Mohammad Ali, Nadhir Al-Ansari, and Hadeel Kareem Jasim. 2014. "GIS and Multicriteria Decision Analysis for Landfill Site Selection in Al-Hashimyah Qadaa." Natural Science 06 (05): 282-304. doi:10.4236/ns.2014.65032.

[9] Ali, Syeda Maria, Aroma Pervaiz, Beenish Afzal, Naima Hamid, and Azra Yasmin. 2014. “Open Dumping of Municipal Solid Waste and Its Hazardous Impacts on Soil and Vegetation Diversity at Waste Dumping Sites of Islamabad City." Journal of King Saud University - Science 26 (1). King Saud University: 59-65. doi:10.1016/j.jksus.2013.08.003.

[10] Alkaradaghi, Karwan, Salahalddin S. Ali, Nadhir Al-Ansari, Jan Laue, and Ali Chabuk. 2019. "Landfill Site Selection Using MCDM Methods and GIS in the Sulaimaniyah Governorate, Iraq." Sustainability (Switzerland) 11 (17). doi:10.3390/su11174530.

[11] Balaguru, Shoba. 2015. "Application of GIS in Solid Waste Management for Coimbatore City," no. November.

[12] Chabuk, Ali, Nadhir Al-Ansari, Hussain Musa Hussain, Jan Laue, Anwer Hazim, Sven Knutsson, and Roland Pusch. 2019. "Landfill Sites Selection Using MCDM and Comparing Method of Change Detection for Babylon Governorate, Iraq." Environmental Science and Pollution Research 26 (35). Environmental Science and Pollution Research: 35325-35339. doi:10.1007/s11356-019-05064-7.

[13] Chang, Ni Bin, G. Parvathinathan, and Jeff B. Breeden. 2008. "Combining GIS with Fuzzy Multicriteria DecisionMaking for Landfill Siting in a Fast-Growing Urban Region." Journal of Environmental Management 87 (1): 139-153. doi:10.1016/j.jenvman.2007.01.011.

[14] Delgado, Otoniel Buenrostro, Manuel Mendoza, Erna López Granados, and Davide Geneletti. 2008. "Analysis of Land Suitability for the Siting of Inter-Municipal Landfills in the Cuitzeo Lake Basin, Mexico." Waste Management 28 (7): 1137-1146. doi:10.1016/j.wasman.2007.07.002.

[15] Demesouka, O. E., A. P. Vavatsikos, and K. P. Anagnostopoulos. 2014. "GIS-Based Multicriteria Municipal Solid Waste Landfill Suitability Analysis: A Review of the Methodologies Performed and Criteria Implemented." Waste Management and Research 32 (4): 270-296. doi:10.1177/0734242X14526632.

[16] Eastman, Ronald, Weigen Jin, Peter A K Kyem, and James Toledano. 1995. "Raster Procedures for MultiCriteria /Multi-0biective Decisions." Measurement 61 (5): 539-547.

[17] Ferronato, Navarro, Vincenzo Torretta, Marco Ragazzi, and Elena Cristina Rada. 2017. "Waste Mismanagement in Developing Countries: A Case Study of Environmental Contamination." UPB Scientific Bulletin, Series D: Mechanical Engineering 79 (3): 185-196.

[18] Fides K. Kirimi, and Edward H Waithaka. 2014. "Determination of Suitable Landfill Site Using Geospatial Techniques and Multi-Criteria Decision Analysis: A Case Study of Nakuru Town, Kenya." International Journal of Science and Research (IJSR) 3 (11): 500-505. https://www.ijsr.net/archive/v3i11/T0NUMTQ4NzY=.pdf. 
[19] Gautam, Sneha, Brema J., and Dhasarathan R. 2020. "Spatio-Temporal Estimates of Solid Waste Disposal in an Urban City of India: A Remote Sensing and GIS Approach." Environmental Technology and Innovation 18. Elsevier B.V.: 100650. doi:10.1016/j.eti.2020.100650.

[20] Hopkins, Lewis D. 1977. "Methods for Generating Land Suitability Maps: A Comparative Evaluation.” Journal of the American Planning Association 43 (4): 386-400. doi:10.1080/01944367708977903.

[21] Ibrahim Mohammed, Habiba, Zulkepli Majid, Norhakim Bin Yusof, and Yamusa Bello Yamusa. 2018. "Analysis of Multi-Criteria Evaluation Method of Landfill Site Selection for Municipal Solid Waste Management." E3S Web of Conferences 34. doi:10.1051/e3sconf/20183402010.

[22] J. R. Adewumi and Fidelis O. Ajibade. 2015. "The Pollution Effects of Indiscriminate Disposal of Wastewater on Soil in Semi-Urban Area." J. Appl. Sci. Environ. Manage. Sept 19 (3): 412-419. doi:10.4314/jasem/v19i3.10.

[23] Jharia, Babita. 2014. "Waste Management : A Study on Raipur Waste Management Private Limited" 6 (1): 199 202.

[24] Karthiheyan, P N, and L Yeshodha. 2016. "Site Selection for Urban Solid Waste Disposal Using Remote Sensing and Open Source GIS In Krishnagiri District, Tamil Nadu." International Journal for Innovative Research in Science \& Technology 2 (10): 233-239.

[25] Kharat, Manoj Govind, Sheetal Jaisingh Kamble, Rakesh D. Raut, Sachin S. Kamble, and Sudheer M. Dhume. 2016. "Modeling Landfill Site Selection Using an Integrated Fuzzy MCDM Approach." Modeling Earth Systems and Environment 2 (2). Springer International Publishing: 1-16. doi:10.1007/s40808-016-0106-X.

[26] Khorram, Alireza, Maryam Yousefi, Seyed Ali Alavi, and Javad Farsi. 2015. "Convenient Landfill Site Selection by Using Fuzzy Logic and Geographic Information Systems: A Case Study in Bardaskan, East of Iran." Health Scope 4 (1). doi:10.17795/jhealthscope-19383.

[27] Kontos, Themistoklis D., Dimitrios P. Komilis, and Constantinos P. Halvadakis. 2005. "Siting MSW Landfills with a Spatial Multiple Criteria Analysis Methodology." Waste Management 25 (8): 818-832. doi:10.1016/j.wasman.2005.04.002.

[28] Malczewski, J. 2000. "On the Use of Weighted Linear Combination Method in GIS: Common and Best Practice Approaches." Transactions in GIS 4 (1): 5-22. doi:10.1111/1467-9671.00035.

[29] Malczewski, Jacek. 2006. “GIS-Based Multicriteria Decision Analysis: A Survey of the Literature." International Journal of Geographical Information Science 20 (7): 703-726. doi:10.1080/13658810600661508.

[30] Moeinaddini, Mazaher, Nematollah Khorasani, Afshin Danehkar, Ali Darvishsefat, and Mehdi Zienalyan. 2010. "Siting MSW Landfill Using Weighted Linear Combination and Analytical Hierarchy Process (AHP) Methodology in GIS Environment (Case Study: Karaj)." Waste Management (New York, N.Y.) 30 (February): 912-920. doi:10.1016/j.wasman.2010.01.015.

[31] Mussa, Ahmed, and K. V. Suryabhagavan. 2019. "Solid Waste Dumping Site Selection Using GIS-Based MultiCriteria Spatial Modeling: A Case Study in Logia Town, Afar Region, Ethiopia." Geology, Ecology, and Landscapes 00 (00). Taylor \& Francis: 1-13. doi:10.1080/24749508.2019.1703311.

[32] Nallusamy, R., Mukesh Goel, Ashutosh Das, and M. Rajamanickam. 2017. “Municipal Solid Waste Disposal Site Selection of Perambalur Town of Southern India Using Fuzzy Gis and Remote Sensing Techniques, Tamilnadu, India." International Journal of Civil Engineering and Technology 8 (9): 663-670.

[33] Nas, Bilgehan, Tayfun Cay, Fatih Iscan, and Ali Berktay. 2010. "Selection of MSW Landfill Site for Konya, Turkey Using GIS and Multi-Criteria Evaluation.” Environmental Monitoring and Assessment 160 (1-4). King Saud University: 491-500. doi:10.1007/s10661-008-0713-8.

[34] Nishant.T, Prakash M.N, Vijith.H. 2010. "Suitable Site Determination for Urban Solid Waste Disposal Using GIS and Remote Sensing Techniques in Kottayam Municipality, India." International Journal of Geomatics and Goescieces 1 (2): 197-210.

[35] Özkan, Barış, Eren Özceylan, and İnci Sarıçiçek. 2019. “GIS-Based MCDM Modeling for Landfill Site Suitability Analysis: A Comprehensive Review of the Literature." Environmental Science and Pollution Research 26 (30): 30711-30730. doi:10.1007/s11356-019-06298-1.

[36] Poorna, Asha, and Vinod P G. 2016. "Solid Waste Disposal Site Selection by Data Analysis Using GIS and Remote Sensing Tools: A Case Study in Thiruvananthapuram Corporation Area." International Journal of Geomatics and Geosciences 6 (4): 1734-1747.

[37] Rahmat, Zeinab Ghaed, Mehdi Vosoughi Niri, Nadali Alavi, Gholamreza Goudarzi, Ali Akbar Babaei, Zeinab Baboli, and Mohsen Hosseinzadeh. 2017. "Landfill Site Selection Using GIS and AHP: A Case Study: Behbahan, Iran.” KSCE Journal of Civil Engineering 21 (1): 111-118. doi:10.1007/s12205-016-0296-9. 
Assessment of Suitable Landfill Site Using Geospatial Techniques: A Case Study of Raipur Urban Region, Chhattisgarh, India

[38] Randazzo, Luciana, Antonio Cusumano, Giuseppe Oliveri, Pietro Di Stefano, Pietro Renda, Marcella Perricone, and Giuseppe Zarcone. 2018. "Landfill Site Selection for Municipal Solid Waste by Using Ahp Method in Gis Environment: Waste Management Decision-Support in Sicily (Italy).” Detritus 2 (1): 78. doi:10.31025/26114135/2018.13656.

[39] RMC. 2018. "EXPRESSION OF INTEREST.” Raipur Municipal Corporation CONTENT. http://nagarnigamraipur.nic.in/Document/rmctender-EOISaronaWTE.pdf.

[40] Saeed, Mohamed Osman, Mohd Sanusi Ahamad, Hamidi Abdul Aziz, and Engineering Campus. 2003. "The Landfill Siting Technology: Challenging and Trends." Waste Management, 1-13.

[41] Salmon Mahini, A., and M. Gholamalifard. 2006. "Siting MSW Landfills with a Weighted Linear Combination Methodology in a GIS Environment." International Journal of Environmental Science and Technology 3 (4): 435-445. doi:10.1007/bf03325953.

[42] Şener, Şehnaz, Erhan Sener, and Remzi Karagüzel. 2011. "Solid Waste Disposal Site Selection with GIS and AHP Methodology: A Case Study in Senirkent-Uluborlu (Isparta) Basin, Turkey." Environmental Monitoring and Assessment 173 (1-4): 533-554. doi:10.1007/s10661-010-1403-x.

[43] Uday Kiran Buddi. 2017. "Solid Waste Disposal Site Selection for Capital Region of Andhra Pradesh Using Multi- Criteria Analysis and GIS" 20 (2016).

[44] Yukalang, Nachalida, Beverley Clarke, and Kirstin Ross. 2017. "Barriers to Effective Municipal Solid Waste Management in a Rapidly Urbanizing Area in Thailand." International Journal of Environmental Research and Public Health 14 (9): 9-14. doi:10.3390/ijerph14091013. 